Vol. 4, No. 1, Juni 2020, hal. 65-75

ISSN 2598-3245 (Print), ISSN 2598-3288 (Online)

DOI: http://doi.org/10.31961/eltikom.v4i1.162

Tersedia online di http://eltikom.poliban.ac.id

\title{
STUDI SKENARIO LOAD SHEDDING PADA PENYULANG DALAM OPERASI SISTEM TENAGA LISTRIK MENGGUNAKAN UNDER FREQUENCY RELAY
}

\author{
Sofyar \\ Program Studi Teknologi Listrik, Akademi Teknik Pembangunan Nasional Banjarbaru, Banjarbaru, Indonesia \\ e-mail: h.sofyar@gmail.com
}

Diterima 26 Januari 2020 - Direvisi 2 April 2020 - Disetujui 19 April 2020

\begin{abstract}
In the operation of an electric power system, the supply of electricity to consumers is said to be good if the magnitude of the voltage and frequency received by specified and still within the tolerance range. Load shedding is carried out automatically using an under frequency relay (UFR). In this study, a computer program simulation was made to analyze the load shedding stages used by PT. PLN (Persero) Barito Sector so that it can be seen the final frequency response after the load is released and then try to provide a proposal for another load release stage to get an excellent frequency response. At the output of the program simulation shown for a maximum loading of $77.9 \mathrm{MW}$, the final frequency is $50.61 \mathrm{~Hz}$, and for a minimum loading of $53 \mathrm{MW}$, the final frequency is 50.02 $\mathrm{Hz}$ with the condition of the system losing one generating unit (first scenario). Then for the condition of the system losing its two most astronomical generating units (the second scenario), at a maximum loading of 77.9 MW and a minimum of $53 \mathrm{MW}$, the final frequency is $49.7 \mathrm{~Hz}$ and $50.3 \mathrm{~Hz}$, respectively.
\end{abstract}

Keywords: computer program simulation, load shedding, under frequency relay.

\section{ABSTRAK}

Pada operasi sistem tenaga listrik, pensuplaian tenaga listrik ke konsumen dikatakan baik apabila besarnya tegangan dan frekuensi yang diterima sesuai dengan yang ditentukan dan masih dalam batas toleransinya. Load shedding atau pelepasan beban pada penyulang dilakukan secara otomatis dengan menggunakan under frequency relay (UFR). Pada penelitian ini dibuat simulasi program komputer untuk menganalisis tahapan load shedding yang digunakan oleh PT. PLN (Persero) Sektor Barito sehingga dapat diketahui respon frekuensi akhir setelah dilakukan pelepasan beban dan selanjutnya mencoba memberikan usulan tahapan peleasan beban yang lain untuk mendapatkan respon frekuensi yang baik. Pada output dari simulasi program diperlihatkan untuk pembebanan maksimum 77,9 MW, frekuensi akhirnya adalah 50,61 Hz dan untuk pembebanan minimum $53 \mathrm{MW}$, frekuensi akhirnya sebesar 50,02 Hz dengan kondisi sistem kehilangan satu unit pembangkit (skenario pertama). Kemudian untuk kondisi sistem kehilangan dua unit pembangkit terbesarnya (skenario kedua), pada pembebanan maksimum 77,9 MW dan minimum $53 \mathrm{MW}$, frekuensi akhinya masing-masing sebesar 49,7 $\mathrm{Hz}$ dan 50,3 $\mathrm{Hz}$.

Kata Kunci: load shedding, simulasi program komputer, under frequency relay.

\section{Pendahuluan}

ISTEM tenaga listrik dalam operasinya dituntut harus dapat memenuhi kebutuhan akan tenaga listrik bagi para konsumen dari waktu ke waktu. Selain itu juga sistem tenaga listrik harus mampu menyediakan tenaga listrik bagi para pelanggan dengan frekuensi yang praktis konstan. Penyimpangan frekuensi dari nilai nominal harus sesuai dengan batas toleransi yang diperbolehkan [1].

Frekuensi adalah suatu indeks atau petunjuk yang penting dari kualitas daya terkait dengan ketidakseimbangan daya aktif antara pembangkit dan beban dan harus dipertahankan dalam kisaran terbatas [2].

Frekuensi akan turun jika daya yang dibangkitkan dalam sistem lebih kecil dari beban sistem dan sebaliknya frekuensi akan naik apabila daya yang dibangkitkan lebih besar dari beban. Untuk itu daya 


\section{Jurnal ELTIKOM : Jurnal Teknik Elektro, Teknologi Informasi dan Komputer}

yang dibangkitkan dalam sistem tenaga listrik harus sama dengan beban sistem [1][3 - 4].

Ketidakseimbangan daya dari suplai daya terhadap beban pada sistem daya ac sering menuju ke pemadaman total (blackouts) [5]. Load shedding adalah suatu bentuk tindakan pelepasan beban secara otomatis atau manual untuk mengamankan operasi unit pembangkit dari kemungkinan blackout [6]. Untuk menghindari gangguan (semi total) dalam sistem ataupun sistem menjadi rusak (collapsed) yang disebabkan terlalu banyak unit pembangkit yang ikut trip karena menjadi berbeban lebih, maka perlu dilakukan pelepasan sebagian beban atau load shedding pada penyulang (feeder) dengan menggunakan under frequency relay (UFR). Biasanya relay-relay statik (under frequency relay) dipasang di feeder yang dipilih berdasarkan jumlah beban yang terpasang di feeder tersebut [7].

Pada operasi suatu pusat listrik tenaga termis, seperti pusat listrik tenaga uap (PLTU) dan pusat listrik tenaga gas (PLTG), penurunan frekuensi yang besar akan sangat mempengaruhi karakteristik kerjanya, sehingga kemampuannya menurun. Disamping itu pengoperasian turbin diluar frekuensi yang diizinkan dapat menimbulkan kerusakan pada sudu-sudu turbin [8].

\section{A. Load Shedding}

Frekuensi (Hertz) merupakan besaran yang dapat dijadikan idikator yang menggambarkan keseimbangan antara pasokan dengan konsumsi energi listrik [1][8][9]. Kondisi sistem dapat mengalami kekurangan pasokan daya disebabkan oleh beban konsumen perlahan meningkat, sedang pada saat yang bersama daya yang dihasilkan pembangkit tidak dapat ditambah lagi, atau yang disebabkan oleh sistem tenaga mengalami beban lebih secara mendadak akibat lepasnya satu atau lebih pembangkit besar pada sistem. Terlepasnya penghantar yang memasok daya ke sistem tenaga juga dapat mengurangi pasokan daya pada sistem. Ketidakseimbangan pasokan kebutuhan daya dapat diatasi dengan dilakukan pelepasan beban atau load shedding dengan tujuan untuk menjaga integritas sistem dan meminimalkan waktu ketidakaktifan pembangkit (outage).

Pada pelaksanaannya dipasang under frequency relay (UFR) pada berbagai feeder distribusi yang dipilih menurut kondisi setempat [1][9][11]. Jumlah UFR minimal cukup untuk melepas beban sebesar unit terbesar sistem dan feeder distribusi yang melayani obyek vital seperti rumah sakit sedapat mungkin tidak diberi UFR.

\section{B. Pembebanan Pada Pembangkit dan Penyulang Gardu Induk (GI) Di PT. PLN (Persero) SektorBarito}

Dalam pelaksanaan operasi sistem tenaga listrik yang terinterkoneksi di Sektor Barito ini untuk periode kondisi darurat berlangsung sangat cepat, yaitu dalam order milidetik sampai detik sehingga sangat mustahil pelaksanaan operasi dapat mengikuti atau memberikan keputusan operasi untuk pengendaliannya hingga kembali ke kondisi normal. Pada kondisi seperti ini pengendali darurat diperlukan dimana implementasinya dilakukan dengan peralatan otomatis tanpa adanya campur tangan dari pelaksana operasi. Implementasi pengendalian yang dimaksud di atas adalah berupa pelepasan sebagian beban (load shedding) pada penyulang (feeder) dengan menggunakan Under Frequency Relay (UFR).

\section{Formulasi}

Hubungan antara kopel penggerak generator dengan perputaran generator [1][12][13]

$$
\left(\mathrm{T}_{\mathrm{G}}-\mathrm{T}_{\mathrm{B}}\right)=I \times \frac{d \omega}{d t}
$$

dengan $\mathrm{T}_{\mathrm{g}}$ adalah kopel penggerak generator. $\mathrm{T}_{\mathrm{b}}$ adalah kopel beban yang membebani generator. $I$ adalah momen Inersia dari generator berserta mesin penggeraknya. $\omega$ adalah kecepatan sudut perputaran generator. Sedangkan frekuensi yang dihasilkan generator adalah:

$$
f=\frac{\omega}{2 \pi}
$$

Besar Daya $\left(P_{0}\right)$ dan kecepatan sudut generator pada keadaan awal [1][11][12] 


$$
\begin{gathered}
\operatorname{Tg} \omega_{0}=\mathrm{P}_{0} \\
\Delta \operatorname{Tg} \omega_{0}=\mathrm{P}_{0}-\mathrm{P}_{\mathrm{b} 0}=0 .
\end{gathered}
$$

Penurunan frekuensi untuk nilai $\mathrm{P}_{\mathrm{s} 0}$ tertentu sesaat setelah gangguan [1][12]

dengan:

$$
\frac{\mathrm{df}}{\mathrm{dt}}=-\frac{\mathrm{fo}}{2 \mathrm{E}} \text { Pso }
$$

$\mathrm{E}=$ energi mekanik dalam system.

Pada prakteknya kebesaran energi kinetis dinyatakan dalam bentuk

$$
\mathrm{H}=\frac{\mathrm{W} \text { kinets }}{\mathrm{P} \text { sistem }}
$$

Sehingga Persamaan 5 dapat diubah menjadi

$$
\frac{\mathrm{df}}{\mathrm{dt}}=-\frac{\mathrm{fo}}{2 \mathrm{H}} \text { Pso. }
$$

Dalam satuan perunit Persamaan 5 menjadi

$$
\frac{\mathrm{df}}{\mathrm{dt}}=-\frac{\text { fo }}{2 \mathrm{H}} \frac{\text { Pso }}{\text { Pgot }- \text { Psot }}
$$

$\left(\frac{d f}{d t}\right)_{0-1}$ adalah nilai $\frac{d f}{d t}$ dalam selang waktu antara $t_{0}$ dan $t_{1}$. Nilai permulaan dari frekuensi dan selisih daya yang dibangkitkan [1][13]

$$
\mathrm{P}_{\mathrm{S} 1}=\mathrm{P}_{1}-\mathrm{P}_{\mathrm{b} 1}
$$

dengan $\mathrm{P}_{1}$ adalah daya yang dibangkitkan pada saat $\mathrm{t}_{1}$ yang dalam hal ini dianggap sama dengan $\mathrm{P}_{0}-$ $\mathrm{P}_{\mathrm{s} 0}$, dengan diasumsikan governor belum beraksi. Nilai frekuensi pada akhir selang waktu $\mathrm{t}_{1}$ adalah:

$$
\mathrm{f}_{1}=\mathrm{f}_{0}+\left(\frac{\mathrm{df}}{\mathrm{dt}}\right){ }_{0-1} \times\left(\mathrm{t}_{1}-\mathrm{t}_{0}\right)
$$

Untuk cara yang sama menghitung $\left(\frac{\mathrm{df}}{\mathrm{dt}}\right)_{0-1}$ maka:

$$
\left(\frac{\mathrm{df}}{\mathrm{dt}}\right)_{1-2}=\frac{\text { fo }}{2 \mathrm{H}} \frac{\text { Po }-(\text { Pso }- \text { Pbr })-P b}{\text { Pgot-Psot }}
$$

dengan $\mathrm{P}_{\mathrm{br}}$ adalah besarnya beban yang dilepas oleh under frequency relay.

\section{Metode Penelitian}

\section{A. Jalannya penelitian}

Gambar 1 memperlihatkan diagram alir langkah-langkah atau tahapan dari jalannya penelitian. Dimulai dengan pengumpulan data-data dan referensi. Kemudian penulis membuat program simulasi dengan kondisi sistem mendekati keadaan sebenarnya. Kemudian penulis mencoba data yang diperoleh dengan menggunakan program simulasi untuk simulasi yang dibuat. Kemudian penulis menghitung respon frekuensi dengan menggunakan tahapan pelepasan beban. Kemudian penulis menganalisis apakah ada respon. Jika ada, usulan tahapan pelepasan beban dibuat. Menganalisis apakah respon frekuensi sudah sesuai. Terakhir membuat kesimpulan. 


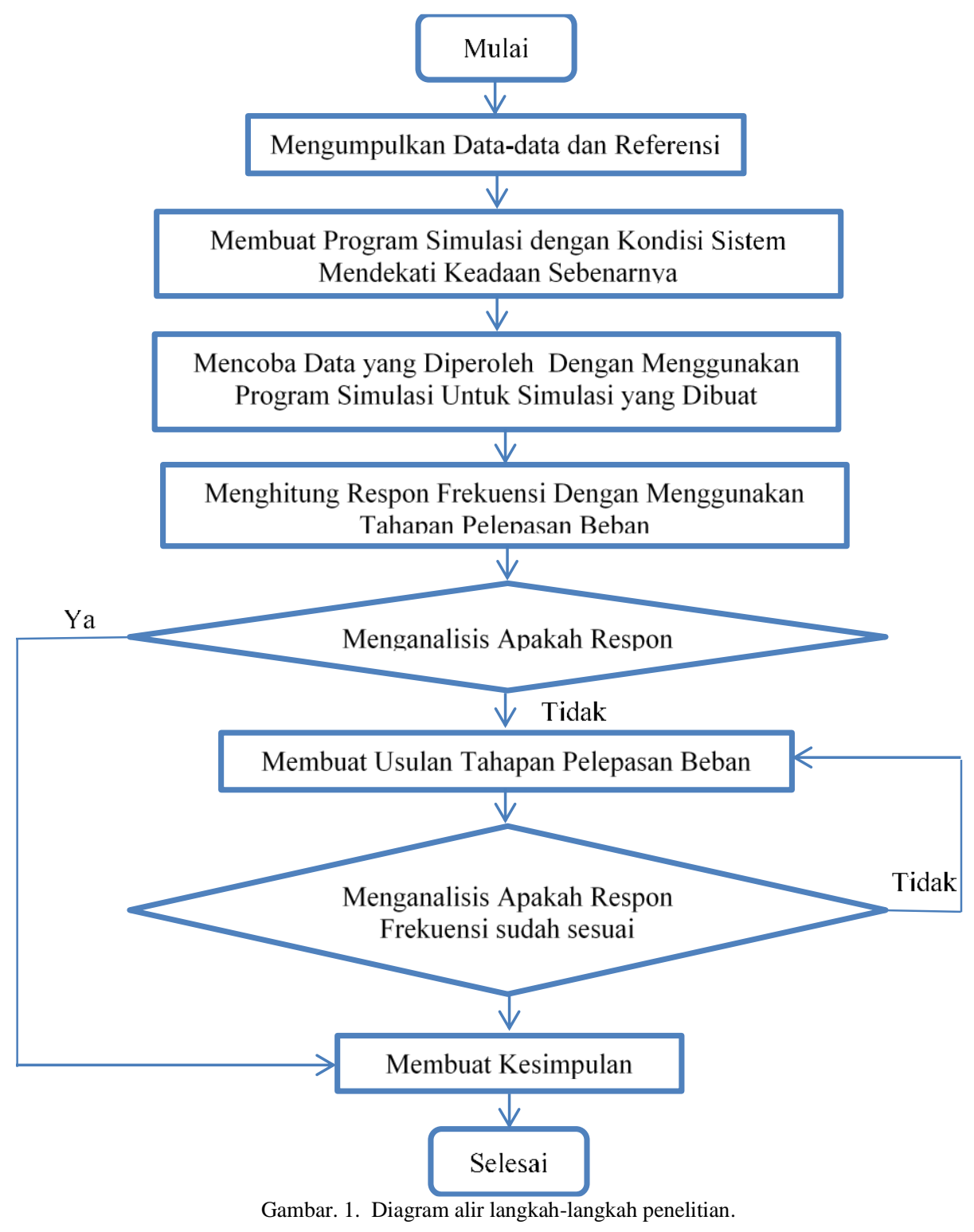

\section{B. Diagram blok perhitungan respon frekuensi}

Untuk perhitungan respon frekuensi ini, pertama dibuat algoritma input data sistem, dan selanjutnya membuat diagram blok untuk perhitungannya seperti terlihat pada Gambar 2.

\section{1) Algoritma input data sistem}

- Daya terpasang unit yang beroperasi pada system.

- Beban sistem sebelum gangguan (pgo).

- Daya terpasang dari unit pembangkit yang mengalami gangguan (psot).

- Daya yang dibangkitkan oleh unit yang terganggu sebelum terjadinya gangguan (pso).

- Besar beban yang dilepaskan pada setiap tahap pelepasan beban (pbr).

- Frekuensi sistem (f).

- Konstanta inersia (I).

- Interval waktu $(\delta \mathrm{t})$.

\section{2) Stategi Operasi Load Shedding Di PT. PLN (Persero) Sektor Barito}

Pembebanan pada penyulang (feeder) di gardu induk (GI) untuk beban minimum dan maksimumnya adalah 64,7 MW dan 94,8 MW. Sedangkan pembebanan pada pembangkit di Sektor Barito pembebanan 


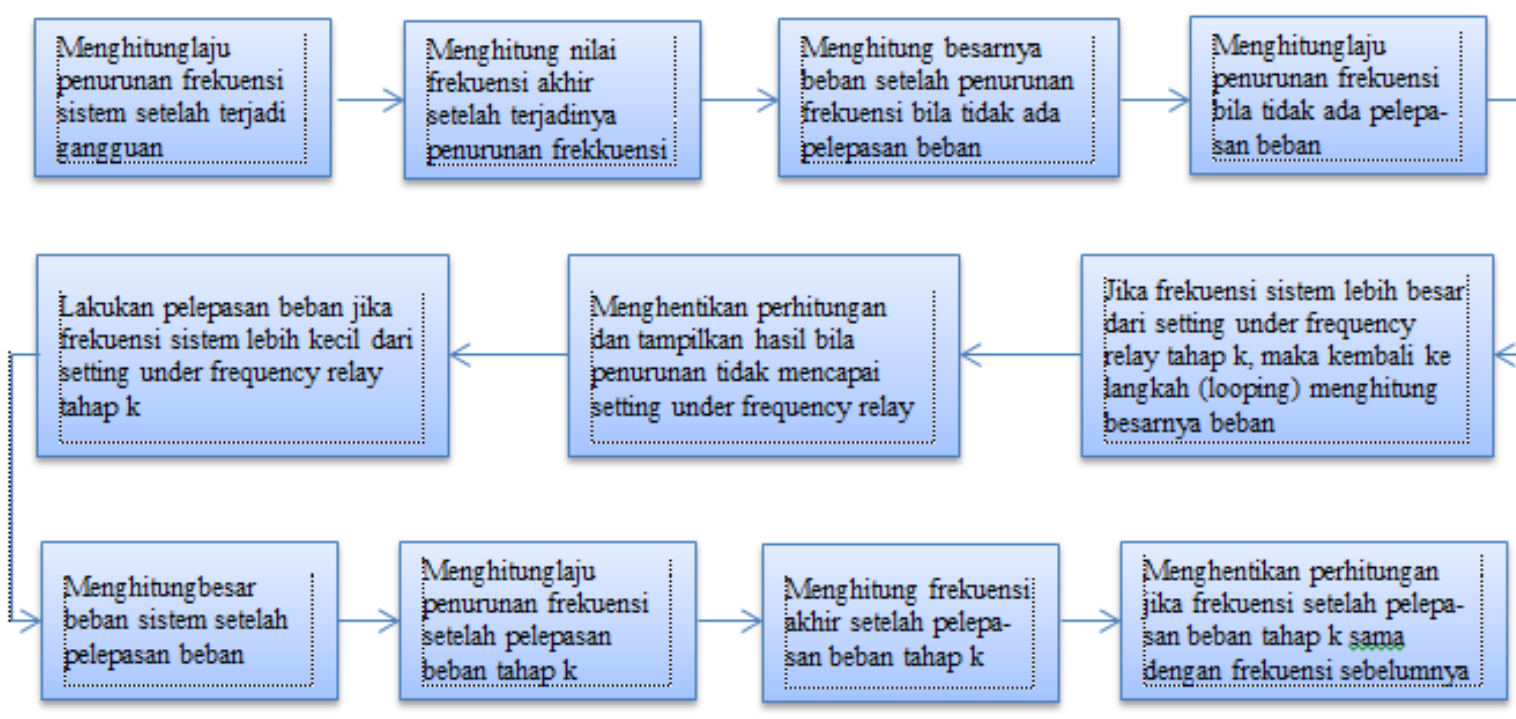

Gambar. 2. Diagram blok perhitungan respon frekuensi.

minimum dan maksimumnya adalah sebesar 70,9 MW dan 104,6 MW [15].

Pada penyulang di gardu induk (GI) yang ada di Sektor Barito dilakukan dengan strategi operasi pelepasan beban dalam tiga tahapan pelepasan, yaitu pada frekuensi $49 \mathrm{~Hz}, 48,5 \mathrm{~Hz}$ dan 48,5 Hz. Adapun total daya yang dilepaskan pada pembebanan minimum dan maksimumnya adalah sebesar 48,82 MW dan 65,64 MW dengan lokasi under frequency relay yang tersebar di semua gardu induk. Untuk masing-masing tahap pelepasan beban dibagi lagi dalam beberapa urutan bekerjanya (trip) dari under frequency relay (UFR) dengan menggunakan waktu tunda (delay time) mulai dari 0,5 sampai 5 detik [15].

\section{Simulasi load shedding}

\section{1) Data yang Diperlukan}

Untuk mensimulasikan pelepasan beban yang dilakukan karena adanya gangguan (lepasnya unit pembangkit) yang menyebabkan penurunan frekuensi sistem, diperlukan data dan pengkondisian sistem seperti berikut:

- Pelepasan beban (load shedding) terjadi disebabkan oleh tripnya unit pembangkit.

- Generator dari semua pembangkit yang ada dianggap bergerak serempak sehingga generator pada sistem dapat dilihat sebagai satu mesin.

- Diasumsikan sistem tenaga listrik di Wilayah Banjarmasin dan sekitarnya terlepas dari interkoneksi dengan sistem tenaga listrik di Wilayah Banua Lima dan Wilayah Kapuas.

- Data pembangkitan yang digunakan adalah data saat pembangkitan maksimum dan pembangkitan minimum.

- Nilai konstanta $\mathrm{H}=4$ untuk semua generator dan $\mathrm{d}=2$ untuk beban.

- Perubahan frekuensi yang diijinkan adalah $\pm 5 \%$.

- Untuk interval waktu setiap interasi adalah 0,1 detik dengan ketelitian 0,001 .

\section{2) Skenario Unit Pembangkit yang Trip}

Skenario Kondisi generator dari unit pembangkit yang trip atau jatuh diasumsikan sebagai berikut.

- Skenario pertama adalah semua generator dari PLTA P.M. Noor tidak aktif dan generator yang trip adalah generator dari unit PLTG Apung dan PLTG Trisakti. Kondisi ini mewakili keadaan dimana PLTA P.M. Noor dalam pemeliharaan rutin dan generator yang trip dipilih dari unit PLTG karena unit pembangkit tersebut mempunyai resiko kerusakan yang lebih tinggi bila dibandingkan dengan unit pembangkit yang lain, terutama pada saat hujan unit PLTG tidak dapat memikul beban yang besar disebabkan karena filter udara sering kemasukan air dan juga kapasitas daya 


\section{Jurnal ELTIKOM : Jurnal Teknik Elektro, Teknologi Informasi dan Komputer}

mampu dari unit tersebut cukup besar sehingga mempunyai pengaruh cukup besar pada sistem.

- Skenario kedua yaitu semua generator dari unit PLTA P.M. Noor dan generator dari PLTG Trisakti tidak aktif, sedangkan generator yang trip adalah generator dari PLTG Apung.

\section{3) Pemrograman skenario load shedding}

Untuk mensimulasikan skenario load shedding digunakan pemrograman komputer Borland Delphi, dimana output dari simulasi tersebut berupa grafik frekuensi sebagai fungsi waktu dan dapat mencetak grafik serta data hasil perhitungan di atas kertas.

\section{HASIL DAN PEMBAHASAN}

Dengan memasukan data kapasitas generator dan bebannya pada program komputer yang dibuat, dapat diketahui respon frekuensi sistem pada saat sistem mulai mengalami gangguan unit pembangkit pada setiap keadaan.

Hasil simulasi dan perhitungan komputer untuk skenario pertama dan skenario kedua baik untuk pembebanan maksimum maupun pembebanan minimum dapat dilihat pada Gambar 3 dan Gambar 4 di bawah ini.

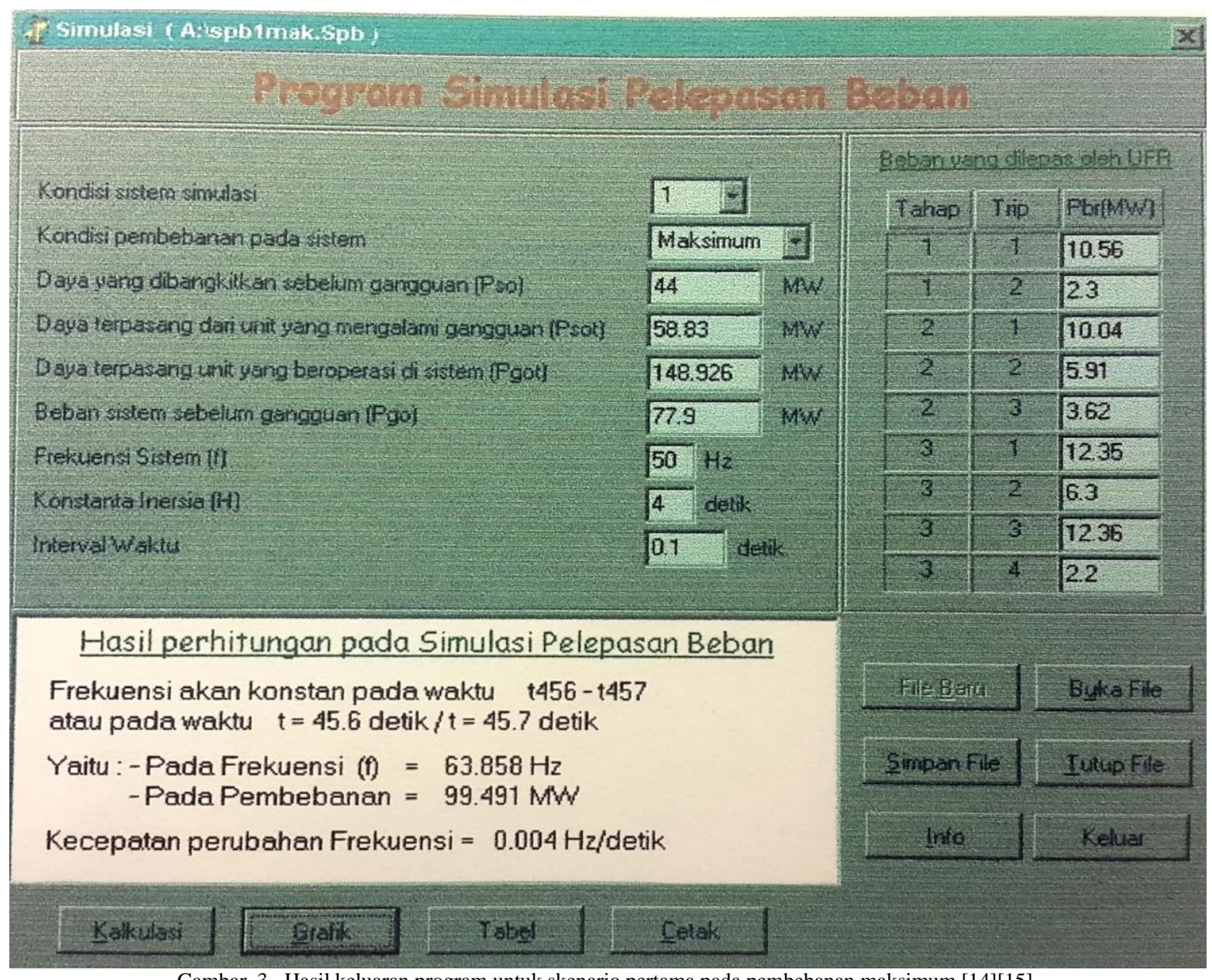

Gambar. 3. Hasil keluaran program untuk skenario pertama pada pembebanan maksimum [14][15].

Dengan mengisikan kolom-kolom pada program simulasi seperti, kondisi sistem simulasi atau kolom untuk pilihan skenario kondisi sistem, kondisi pembebanan pada sistem, juga kita harus mengisikan nilai daya yang dibangkitkan dan besarnya pembebanan sistem sebelum gangguan. Demikian juga pada kolom besarnya daya terpasang pada unit yang beroperasi dan daya terpasang pada unit yang mengalami gangguan harus di isikan nilainya. Untuk kolom frekuensi sistem, konstanta inersia dan interpal waktu harus kita isikan. menekan tombol kalkulasi pada tampilan simulasi pemrograman, selanjutnya akan ditampilkan keluaran (output) seperti pada Gambar 3 di atas. Tampak diperlihatkan pelepasan beban 


\section{Jurnal ELTIKOM : Jurnal Teknik Elektro, Teknologi Informasi dan Komputer}

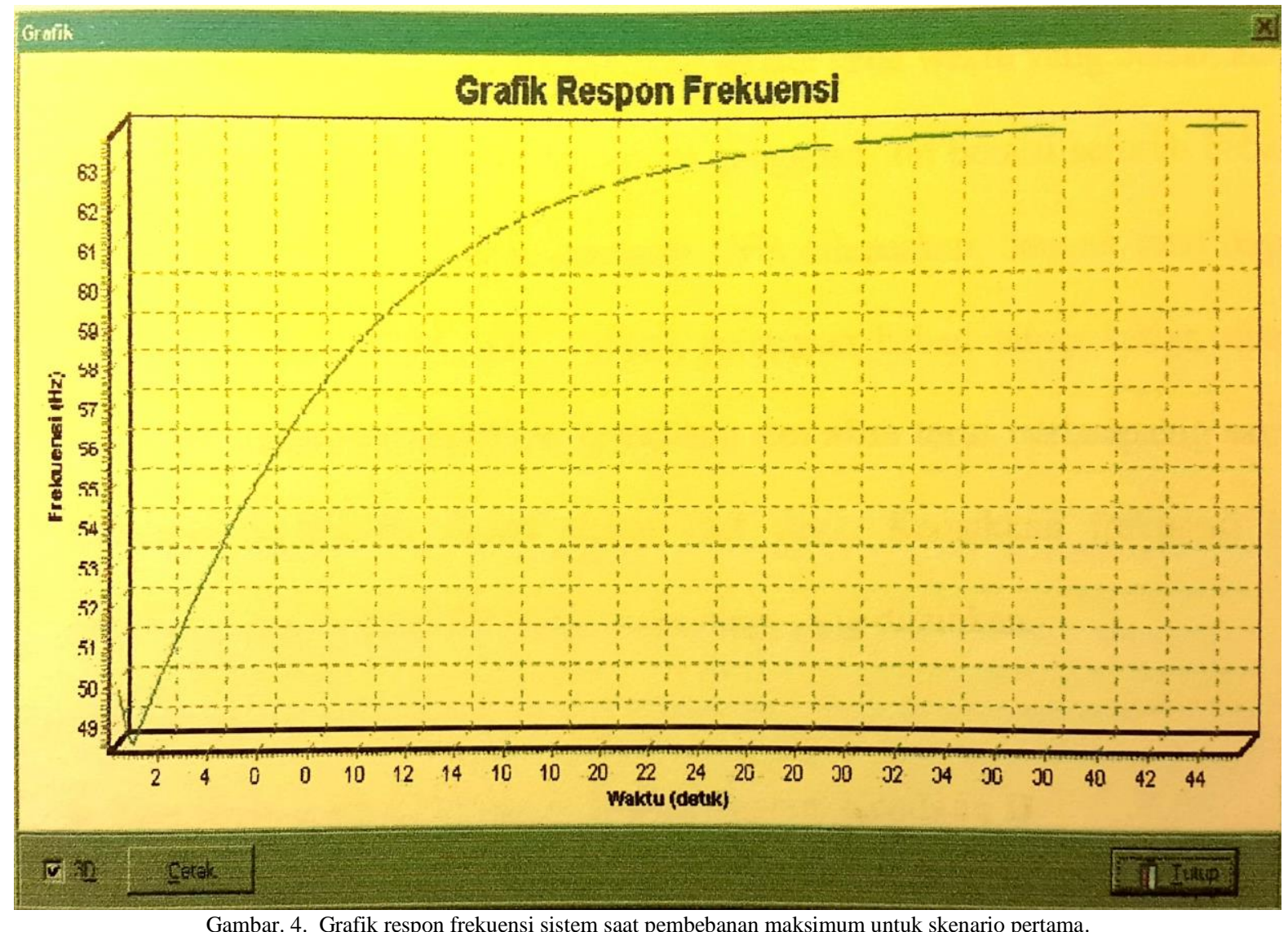

atau load shedding untuk kondisi pembebanan maksimum pada sistem dengan skenario pertama (1), dimana sistem kehilangan dua unit pembangkit. Hasilnya memperlihatkan bahwa pelepasan beban berlangsung dalam tiga tahap pelepasan dengan masing-masing jumlah trip pada setiap tahapan yang berbeda-beda. Untuk tahap pertama atau 1 ada dua trip (feeder yang dilepas beban), sedangkan untuk tahap kedua dan ketiga masing-masing ada 3 dan 4 trip dengan total daya yang dilepas sebesar 65,64 MW. Pada gambar 3 juga diperlihatkan nilai kecepatan perubahan frekuensinya yaitu sebesar $0,004 \mathrm{~Hz}$ per detik dan waktu (t) dimana frekuensi akan kembali konstan setelah adanya gangguan dan pelaksanaan pelepasan beban.

Untuk menampilkan hasil keluaran dari respon frekuensi sistemnya dalam bentuk grafik diperlihatkan seperti pada Gambar 4 di atas, dengan sebelumnya menekan tombol grafik pada tampilan program simulasi pelepasan beban. Pada Gambar 4 memperlihatkan frekuensi sistem pada saat terjadinya gangguan dan pada kondisi setelah dilakukannya pelepasan beban atau load shedding. Pada saat terjadinya gangguan pada kedua unit pembangkit besar dalam sistem, frekuensi sistem akan turun dari $50 \mathrm{~Hz}$ ke nilai frekuensi kurang dari $49 \mathrm{~Hz}$ dalam waktu kurang dari 1 detik. Kemudian dilakukan pelepasan beban pada penyulang atau feeder di gardu induk sehingga respon frekuensi sistem menunjukan adanya kenaikan frekuensi sistem dengan kecepatan 0,004 Hz/detik sampai selama lebih dari 44 detik (tepatnya 45,6 detik), frekuensi akan kembali konstan pada nilai frekuensi sistem 63,86 $\mathrm{Hz}$.

Dengan cara yang sama untuk pembebanan maksimum dengan sistem kehilangan 1 unit pembangkit (skenario kedua) dan pembebanan minimum untuk kedua macam skenario gangguan diketahui masingmasing frekuensi sistem akan konstan pada nilai frekuensi $50,27 \mathrm{~Hz}, 51,11 \mathrm{~Hz}$ dan 58,897 Hz. Hal tersebut berarti ada frekuensi sistem yang melebihi nilai yang diperbolehkan yaitu $\pm 5 \%$ dari $50 \mathrm{~Hz}$.

\section{A. Usulan Tahapan Pelepasan Beban}

Dari hasil perhitungan di atas diketahui, pada skenario pertama dengan kehilangan 2 unit pembangkit 
TABEL 1

TAHAP PELEPASAN BEBAN DAN SETTING FREKUENSI YANG DIUSULKAN UNTUK BEBAN SISTEM MAKSIMUM DAN BEBAN SISTEM MINIMUM [14][15]

\begin{tabular}{|c|c|c|c|c|c|c|}
\hline \multicolumn{3}{|c|}{$\begin{array}{l}\text { PELEPASAN BEBAN } \\
\text { (LOAD SHEDDING) }\end{array}$} & \multicolumn{2}{|c|}{$\begin{array}{c}\text { SETTING UNDER } \\
\text { FREQUENCY RELAY (UFR) }\end{array}$} & \multicolumn{2}{|c|}{$\begin{array}{c}\text { LOKASI UNDER } \\
\text { FREQUENCY RELAY (UFR) }\end{array}$} \\
\hline \multirow{2}{*}{$\begin{array}{l}\text { TAHAP } \\
\text { PELEPASAN }\end{array}$} & \multicolumn{2}{|c|}{$\begin{array}{l}\text { BEBAN YANG DILEPAS SAAT } \\
\text { PEMBEBANAN SISTEM }\end{array}$} & \multirow{2}{*}{$\begin{array}{l}\text { FREKUENSI } \\
\qquad(\mathrm{Hz})\end{array}$} & \multirow{2}{*}{$\begin{array}{l}\text { WAKTU TUNDA } \\
\text { (DELAY TIME) } \\
\text { (DETIK) }\end{array}$} & \multirow{2}{*}{$\begin{array}{l}\text { GARDU INDUK } \\
\text { (GI) }\end{array}$} & \multirow{2}{*}{$\begin{array}{l}\text { PENYULANG } \\
\text { (FEEDER) }\end{array}$} \\
\hline & $\begin{array}{l}\text { MAKSIMUM } \\
(\mathrm{MW})\end{array}$ & $\begin{array}{l}\text { MINIMUM } \\
\text { (MW) }\end{array}$ & & & & \\
\hline \multirow{2}{*}{ Pertama } & 6,75 & 2,08 & \multirow{3}{*}{49,5} & \multirow{3}{*}{0,5} & \multirow{3}{*}{$\begin{array}{l}\text { Trisakti } 150 \mathrm{Kv} \\
\text { Seberang Barito }\end{array}$} & \multirow{2}{*}{$\begin{array}{l}\text { TS. Gatot } \\
\text { SB. } 8\end{array}$} \\
\hline & 1,64 & 4,93 & & & & \\
\hline Sub Total & 8,39 & 7,01 & & & & \multirow{4}{*}{$\begin{array}{l}\text { SB.1 } \\
\text { SB.6 }\end{array}$} \\
\hline \multirow{2}{*}{ Kedua } & 4,27 & 3,94 & \multirow{3}{*}{49} & \multirow[b]{2}{*}{1,0} & \multirow[t]{2}{*}{ Seberang Barito } & \\
\hline & 1,97 & 5,59 & & & & \\
\hline Sub Total & 6,24 & 9,53 & & & \multirow{4}{*}{$\begin{array}{l}\text { Trisakti } 150 \mathrm{Kv} \\
\text { Seberang Barito }\end{array}$} & \\
\hline \multirow{2}{*}{ Ketiga } & 3,81 & 6,57 & \multirow{3}{*}{48,6} & \multirow{3}{*}{0,0} & & \multirow{3}{*}{$\begin{array}{l}\text { TS.16 } \\
\text { SB. } 4\end{array}$} \\
\hline & 0,33 & 0,99 & & & & \\
\hline \multirow[t]{2}{*}{ Sub Total } & 4,14 & 7,56 & & & & \\
\hline & & 1,20 & \multirow{4}{*}{48,5} & \multirow{3}{*}{1,0} & \multirow{3}{*}{ TRISAKTI $70 \mathrm{KV}$} & \\
\hline \multirow{3}{*}{ Keempat } & 3,10 & 1,50 & & & & TS.9 \\
\hline & 2,20 & 1,20 & & & & TS.14 \\
\hline & 4,50 & 3,08 & & 2,0 & Cempaka $70 \mathrm{Kv}$ & CP. 12 \\
\hline Sub Total & 12,90 & 6,98 & & & & \\
\hline & 2,63 & 0,66 & & & Seberang Barito & SB.7 \\
\hline & 2,10 & 0,46 & & & & BM.7 \\
\hline Kelima & 5,02 & 5,02 & 48,4 & 1,5 & BANJARMASIN & BM.13 \\
\hline & 3,60 & 2,39 & & & & BM.14 \\
\hline Sub Total & 13,35 & 8,53 & & & & \\
\hline & 0,99 & 0,66 & & 2,0 & Seberang Barito & SB.3 \\
\hline Keenam & 4,07 & 1,46 & & & Cemnaka $70 \mathrm{Ky}$ & CP.4 \\
\hline Keenam & 0,69 & 0,28 & 48,2 & & Cempaka $70 \mathrm{Kv}$ & CP.7 \\
\hline & 3,04 & 1,76 & & 2,5 & & BM.9 \\
\hline & 3,61 & 1,85 & & & Banjarmasin & BM.12 \\
\hline Sub Total & 12,40 & 6,01 & & & & \\
\hline Total & 57,42 & 45,62 & & & & \\
\hline
\end{tabular}

untuk pembebanan maksimum 77,9 MW, nilai frekuensi akhir setelah pelepasan beban yaitu 65,64 Hz, jauh melebihi nilai kenaikan frekuensi yang diperbolehkan yaitu $52,5 \mathrm{~Hz}( \pm 5 \%)$. Begitu juga pada skenario kedua untuk pembebanan minimum $53 \mathrm{MW}$, frekuensi akhir setelah pelepasan beban menunjukan nilai yang tinggi 58,897 Hz lebih tinggi dari harga toleransinya. Hal tersebut dikarenakan beban yang dilepaskan oleh under frequency relay (UFR) lebih besar bila dibandingkan dengan daya sistem yang hilang, sehingga pelepasan beban yang semula diharapkan dapat mengembalikan frekuensi sistem ke harga normal setelah lepas unit pembangkit malah menimbulkan masalah baru, yaitu sistem menjadi over frequency (frekuensi lebih). Karena itu diusulkan suatu tahapan pelepasan beban yang dapat memenuhi kompromi kondisi sistem yang sudah diterangkan sebelumnya, yaitu dengan membagi tahapan load shedding atau pelepasan beban menjadi 6 (enam) tahap pelepasan, dimana setting frekuensi diambil $0,5 \mathrm{~Hz}$ lebih besar dari setting frekuensi milik PT. PLN dan ada penghilangan (diganti) 2 penyulang (feeder) karena melayani atau mensuplai obyek penting yaitu rumah sakit.

Dengan tetap menggunakan skenario kondisi sistem seperti sebelumnya, hasil perhitungan dapat dilihat pada gambar simulasi dan gambar grafik di bawah.

Dari hasil perhitungan dengan program simulasi pelepasan beban (Gambar 5) diperlihatkan bahwa pada kondisi pembebanan sistem maksimum dengan skenario kondisi sistem dalam keadaan kehilangan dua unit pembangkit (skenario 1) dan daya yang dibangkitkan sebebelum gangguan (Pso ) sebesar 44 MW, sedangkan beban sistem sebelum gangguan adalah 77,9 MW. Pelepasan beban atau load shedding dilakukan dalam 5 (lima) tahapan pelepasan beban dengan laju perubahan frekuensi sebesar $0,005 \mathrm{~Hz}$ per detik dan frekuensi sistem setelah pelepasan beban akan berada pada nilai frekuensi (perubahan frekuensi akan terhenti atau konstan) 50,605 Hz dengan total daya yang dilepaskan sebesar 45,02 MW.

Adapun untuk output hasil perhitungan respon frekuensi sistem dalam bentuk grafik dapat dilihat pada Gambar 6 di atas. Pada Gambar 6 grafik respon frekuensi di atas memperlihatkan respon frekuensi 


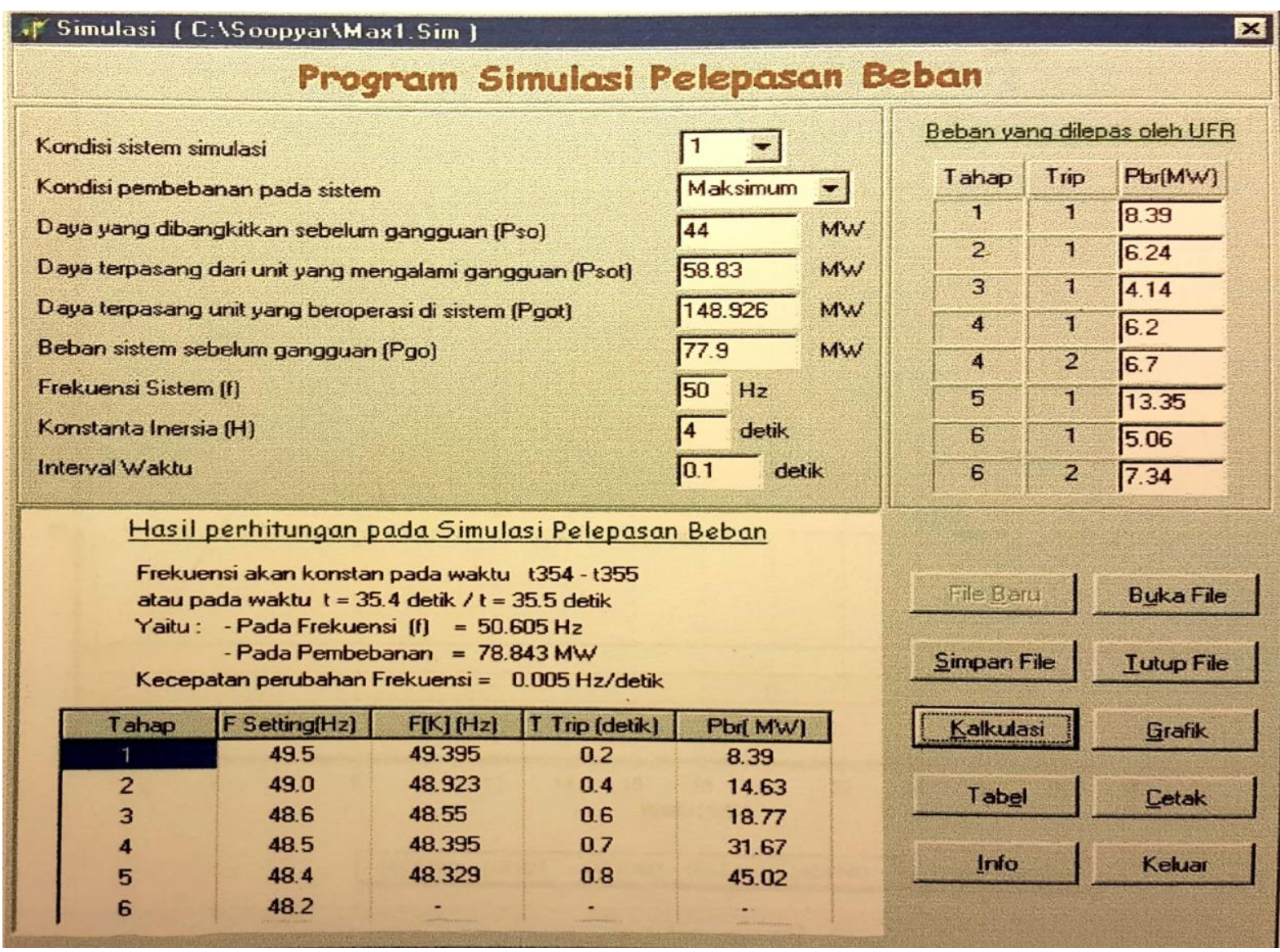

Gambar. 5. Hasil keluaran program untuk skenario pertama pada pembebanan maksimum [1, 11].

sistem setelah terjadinya gangguan ditandai dengan penurunan frekuensi sistem dari frekuensi nominalnya $(50 \mathrm{~Hz})$ sampai ke nilai setting dari under frequency relay untuk load shedding tahap pertama yaitu pada frekuensi 49,5 Hz. Perlu diketahui bahwa untuk load shedding tahap pertama tersebut, di lalukan dalam dua kali pelepasan beban yaitu pada penyulang atau feeder TS Gatot pada gardu induk Trisakti $150 \mathrm{KV}$ dan fedder SB 8 pada gardu induk Seberang Barito. Pada load shedding tahap pertama tersebut frekuensi sistem menunjukan nilai frekuensi $49,395 \mathrm{~Hz}$ dan masih menunjukan penurunannya sampai melewati nilai setting frekuensi untuk load shedding tahap kedua yaitu pada nilai frekuensi $49 \mathrm{~Hz}$. Adapun daya yang sudah dilepaskan pada load shedding tahap pertama dan kedua adalah sebesar 14, $63 \mathrm{MW}$ dan frekuensi sistem pada load shedding tahap kedua menunjukan nilai frekuensi 48,923 Hz. Setelah load shedding tahap kedua ini dilakukan, frekuensi sistem masih tetap mengalami penurunan sampai melewati setting frekuensi dari under frequency relay untuk load shedding tahap ketiga, yaitu pada frekuensi $48,6 \mathrm{~Hz}$ dan frekuensi sistem menunjukan nilai $48,55 \mathrm{~Hz}$ dengan nilai daya yang sudah dilepaskan sebesar 18,77 MW.

Sampai pada ketiga tahap load shedding tersebut sudah enam feeder yang dilepaskan, namun penurunan frekuensi sistem masih tetap berlanjut hingga nilai setting frekuensi untuk load shedding tahap keempat $(48,5 \mathrm{~Hz})$ terlampaui sehingga dilakukan lagi pelepasan beban sebesar 12,90 MW sehingga total beban yang sudah dilepaskan adalah sebesar 31,67 MW dan frekuensi sistem menunjukan nilai frekuensi di nilai 48,395 Hz. Pada tahapan load shedding tersebut frekuensi masih terus menurun sehingga load shedding tahap kelima terjadi setelah setting frekuensinya terlampaui yaitu pada setting 48,4 Hz dengan total daya yang dilepaskan sebesar 45,02 MW dengan total penyulang atau feeder yang dilepaskan sebanyak 14 feeder. Frekuensi sistem pada load shedding tahap kelima tersebut menunjukan nilai frekuensi di angka 48,329 Hz.

Pada nilai frekuensi sistem $48,329 \mathrm{~Hz}$ tersebut penurunan frekuensi sistem tidak terjadi lagi dan cenderung menunjukan kenaikkan hingga sampai ke nilai 50,605 Hz dan cenderung kembali konstan di 


\section{Jurnal ELTIKOM : Jurnal Teknik Elektro, Teknologi Informasi dan Komputer}

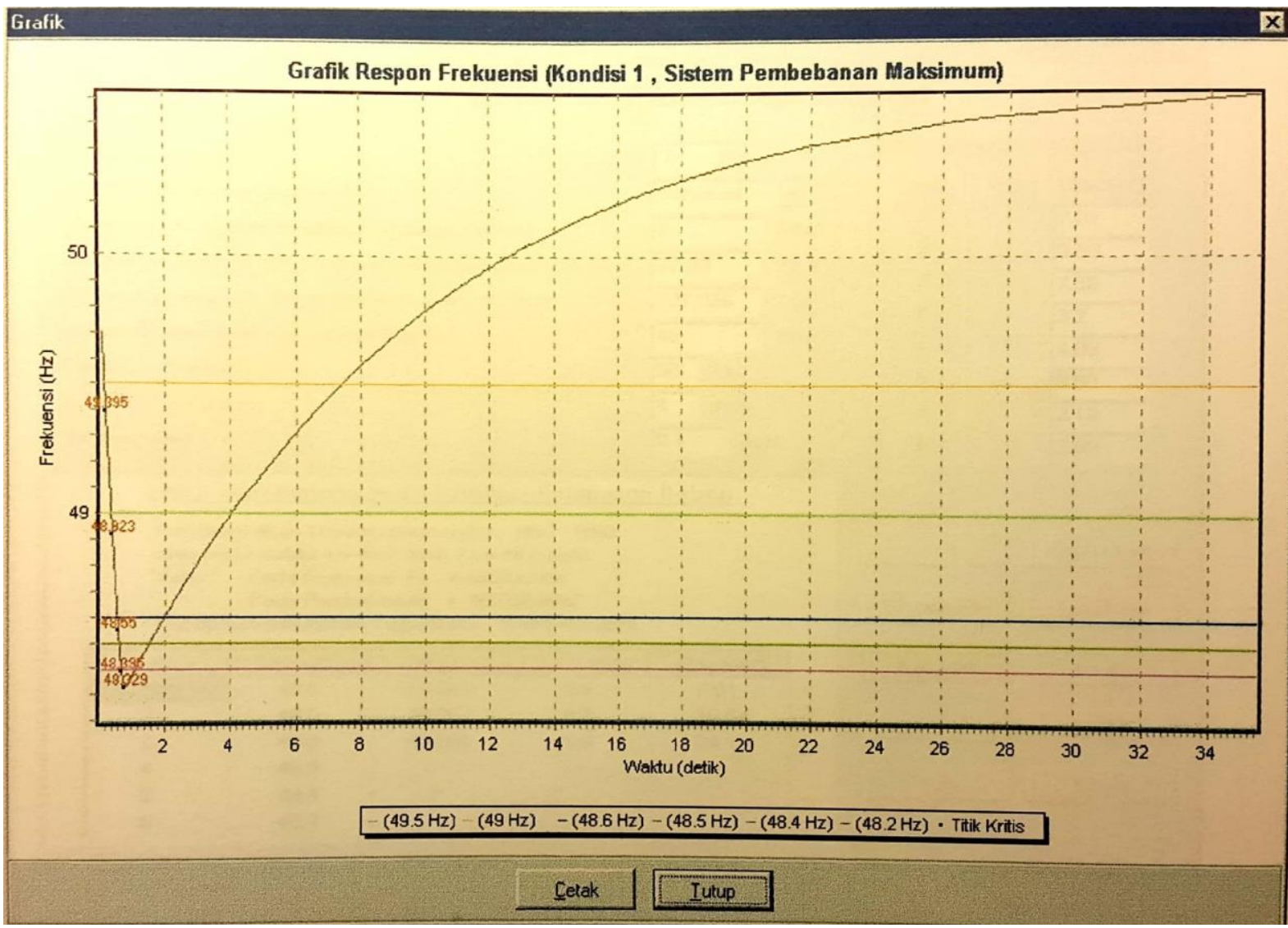

Gambar. 6. Grafik respon frekuensi sistem saat pembebanan maksimum untuk skenario pertama.

nilai tersebut pada waktu t 35,4 detik dan t 35,5 detik.

Demikian juga dengan cara yang sama untuk skenario pertama pada pembebanan sistem minimum sebesar $53 \mathrm{MW}$ dengan sebelumnya mengisikan data-data yang diperoleh dari PT. PLN (persero) pada kolom-kolom yang ada pada tampilan program simulasi pelepasan beban atau load shedding didapatkan hasil perhitungan simulasi pelepasan bebannya dimana load shedding dilakukan dalam empat tahap pelepasan beban dengan total daya yang dilepaskan sebesar 31,08 MW dan penurunan frekuensi sistem dari mulai terjadinya gangguan sistem dan setelah dilakukan pelepasan beban yaitu pada frekuensi $48,496 \mathrm{~Hz}$, selajutnya frekuensi sistem mulai mengalami kenaikan menuju ke harga nominalnya dan cenderung konstan diharga frekuensi 50,016 Hz pada waktu t 43,3 detik.

Untuk kondisi sistem pada skenario kedua dengan kondisi pembebanan maksimum dan minimum dengan cara sama seperti pada skenario pertama, diperoleh hasil perhitungannya sebagai berikut.

- Pada pembebanan maksimum load shedding terjadi dalam empat tahap pelepasan dengan total daya yang dilepaskan sebesar 31,67 MW, penurunan frekuensi sistem yang terjadi sampai pada nilai frekuensi 48,486 Hz dan setelah itu kembali menunjukan kenaikan frekuensi menuju ke nilai frekuensi nominalnya $(50 \mathrm{~Hz})$. Frekuensi sistem pada kondisi pembebanan maksimum skenario kedua ini cenderung konstan pada frekuensi $49,7 \mathrm{~Hz}$.

- Pada kondisi pembebanan minimumnya, load shedding hanya dilakukan dalam tiga tahapan dengan total daya yang dilepaskan sebesar 24,1 MW dari 6 feeder yang ada di gardu induk Trisakti $150 \mathrm{KV}$ dan gardu induk Seberang Barito. Frekuensi sistem pada saat mulai gangguan sampai dengan setelah dilakukan load shedding menunjukan penurunan frekuensi sampai ke nilai frekuensi sistem 48,561 Hz dan setelah itu cenderung naik sampai ke nilai frekuensi sistem 50,032 Hz pada waktu t 46,8 detik.

Perlu dberikan penjelasan bahwa karena kesulitan dan keterbatasan penulis untuk mendapatkan data yang terbaru (up to date) baik mengenai unit pembangkit mana yang menjadi unit pembangkit terbesar dalam sistem tenaga di PT. PLN (persero) Sektor Barito, besarnya pembebanan maksimum dan 


\section{Jurnal ELTIKOM : Jurnal Teknik Elektro, Teknologi Informasi dan Komputer}

minimum pada pembangkit dan di gardu induk, serta data mengenai tahapan pelepasan beban dan setting frekuensinya maka pada penelitian ini penulis menggunakan data pada tahun 2000. Akan tetapi dengan metode yang sama, tinggal menggantikan angka dan besarnya nilai dari parameter-parameter yang digunakan pada program simulasi load shedding ini akan diketahui respon frekuensinya.

\section{KESIMPULAN}

Pada hasil keluaran program komputer dari tahapan pelepasan beban yang diusulkan, diperlihatkan bahwa frekuensi akhir setelah pelepasan beban untuk masing-masing skenario dan pembebanan sistem, yaitu untuk skenario load shedding pertama pada pembebanan sistem maksimum 77,9 MW, frekuensi akhirnya adalah $50,61 \mathrm{~Hz}$. Adapun pada skenario yang sama tetapi dengan pembebanan sistem minimum $53 \mathrm{MW}$, frekuensi akhirnya sebesar 50,02 Hz. Pada skenario load shedding kedua pada pembebanan sistem maksimum 77,9 MW, frekuensi akhirnya adalah 49,7 Hz. Untuk pembebanan sistem minimum pada skenario load shedding yang sama, frekuensi akhirnya adalah sebesar 50,03 Hz.

Jadi frekuensi akhir sistem setelah dilakukan pelepasan beban atau load shedding untuk skenario load shedding pertama maupun yang kedua pada pembebanan sistem maksimum dan pembebanan sistem minimum adalah besarnya masih dalam batas frekuensi yang diperbolehkan.

\section{DAFTAR PUSTAKA}

[1] Djiteng Marsudi, "Operasi sistem tenaga listrik," Penerbit Graha Ilmu, Edisi Kedua, Cetakan Pertama, 2006

[2] Changgang Li, Yanli Sun, and Yawei Yu,"An Under-frequency load shedding scheme with continuous load control proportional to frequency deviation," IOP Publishing, 2017 2nd Asia Conference on Power and Electrical Engineering, 2017.

[3] Irrine Budi Sulistiawati, Aga Dia Priasmoro, Abraham Lomi, Ardyono Priyadi, "Study of static under frequency load shedding on IEEE 3 generators 9 bus system caused of transient condition," Journal of Telecommunication, Electronic and Computer Engineering, 2016.

[4] Scott Manson, Greg Zweigle, and Vinod Yedidi,"Case study: An adaptive under frequency load shedding system," IEEE Transactions on Industry Application. vol. 50, no. 3 May/June 2014.

[5] T Sucita, Y Mulyadi, and W S Saputra,'Load shedding analysis because of contingency demage (N-2) at transmission line 150 kV subsystem cirata," International Symposium on Materials and Electrical Engineering (ISMEE), 2017.

[6] Kaushik Das, Antonios Nitsas, Mufit Altin, Anca D Hansen, and Poul E Sorensen,'Improved load shedding scheme considering distributed generation," IEEE Transactions on Power Delivery, 2017.

[7] Ghazanfar Shahgholian, Mahdi Ebrahimi Salary, "Effect load shedding strategy on Interconnected power systems stability when a blackout occurs," International Journal of Computer and Electrical Enginnering, Vol. 4, No.2, April 2012.

[8] Gazmend Kabashi, Skender Kabashi,"Review of under frequency load shedding program of Kosovo power system based on ENTSO-E requirements," International Journal of Electrical and Computer Engineering (IJECE), Vol.8, No.2, April 2018.

[9] Standar Perusahaan Umum Listrik Negara,"Pola pengamanan sistem," SPLN 52-3, Bagian Ketiga, Perusahaan Umum Negara, Jakarta, 1983.

[10] Qin Li, Zhiqiang Xu, Yi Liu, Jun Lu, Zesheng Hu, "Power precise load shedding control strategy considering user demand response clustering," IOP Conf. Series: Material Science and Engineering, 2019.

[11] Arismunandar A, "Buku pegangan teknik teaga listrik," Jilid III, PT.Pradnya Paramita, Jakarta, 1979.

[12] Zuhal, "Dasar tenaga listrik," Cetakan kedua, Penerbit ITB, Bandung, 1991.

[13] Kadir A, "Pembangkit tenaga listrik," Penerbit Universitas Indonesia, Jakarta, 1996.

[14] Skema pelepasan beban, PT. PLN (Persero) Wilayah VI Sektor Barito, Banjarbaru, 2000.

[15] Data beban penyulang gardu induk dan pembangkit bulan juni 2000, PT. PLN (Persero) Wilayah VI Sektor Barito, Banjarbaru, 2000. 